\title{
Cognitive and Balance Performance among Elderly in Nursing Home
}

\author{
Mathilda Albertina, Herdiman Bernard Purba, Siti Annisa Nuhonni
}

Department of Physical Medicine and Rehabilitation, Faculty of Medicine, University of Indonesia, Cipto Mangunkusumo Hospital, Jakarta, Indonesia

\begin{abstract}
Introduction: Cognitive disorders have associated with incidence of fall. Cognitive problem is more frequent in elderly living in nursing homes compared to those who live in community. The aim of this study is to determine correlation between balance performance and cognitive status among elderly in nursing home.

Methods: This study was conducted in a nursing home in Jakarta. Balance performance was evaluated using Timed Up and Go (TUG) test and Berg Balance Scale (BBS), while cognitive status was examined using Mini Mental State Examination (MMSE).

Results: There were 35 participants, consisted of male $10(28.6 \%)$ and female $25(71.4 \%)$ with median aged 69 years old, included in this study. Median MMSE result was 21 (6-30). The median result of TUG was 14.13 (9.66-88.50) seconds. The median BBS result was 50 (18-56). MMSE have negative strong correlation with TUG $(\mathrm{r}=-0.693 ; \mathrm{p}=0.000)$ and positive strong correlation with BBS $(\mathrm{r}=0.640 ; \mathrm{p}$ $=0.000)$.
\end{abstract}

Conclusion: Cognitive function has strong correlation with balance performance among elderly in nursing home. Therefore, cognitive aspect should be included in fall prevention program.

Keywords: Balance, cognitive, elderly, nursing home 


\begin{abstract}
ABSTRAK
Pendahuluan: Gangguan kognitif memiliki hubungan dengan kejadian jatuh. Masalah kognitif lebih sering terjadi pada lansia yang tinggal di panti jompo dibandingkan dengan mereka yang tinggal di komunitas. Tujuan penelitian ini adalah menentukan korelasi antara status kognitif dengan keseimbangan pada lansia di panti jompo.

Metode: Penelitian ini dilakukan di panti jompo di Jakarta. Performa keseimbangan dievaluasi menggunakan tes Time Up dan Go (TUG) dan Skala Keseimbangan Berg (BBS), sementara status kognitif diperiksa dengan Mini Mental State Examination (MMSE).

Hasil: Teradapat 35 partisipan, terdiri dari pria 10(28.6\%) dan wanita 25(71.4\%) dengan nilai tengah berumur 69 tahun, yang disertakan pada penelitian ini. Nilai tengah hasil MMSE adalah 21 (6-30). Nilai tengah hasil dari TUG adalah 14.13 (9.66-88.50) detik. Nilai tengah hasil BBS adalah 50 (18-56). MMSE memiliki korelasi negatif yang kuat dengan TUG $(r=-0.693 ; p=0.000)$ dan korelasi positif yang kuat dengan BBS $(r=0.640 ; p=0.000)$.
\end{abstract}

Kesimpulan: Fungsi kognitif memiliki korelasi yang kuat dengan performa keseimbangan diantara lansia di panti jompo.

Kata kunci: Keseimbangan, Kognitif, Lansia, Panti Jompo

\section{Correspondent Detail:}

\section{Mathilda Albertina}

Email: mathilda.md@gmail.com

Faculty of Medicine University of Indonesia Jakarta, Indonesia

\section{INTRODUCTION}

Improvement of health services result in increase of life expectancy and percentage of elderly population. In Indonesia, citizen above 60 years old in 2017 is $9.03 \%$ among population and is estimated to reach $15.8 \%$ in 2035. ${ }^{1}$ Therefore, health problems in old age deserve more attention. One of them is high incidence of falls. The mean fall rate among elderly is 0.65 falls per person-year in community, and 1.7 for those living in nursing homes. $^{2}$

Balance is the ability of the body to maintain equilibrium or prevent fall. Balance involves complex motor control. Sensory systems detect body position and movements. Those impulses send to central nervous systems that select and integrate incoming inputs to create the right perception. Central nervous systems then select muscle contraction pattern and sends impulse to the motor systems to give adequate musculoskeletal systems in controlling body position. Besides that, central nervous systems also play roles in anticipation movement and adjustment. $^{3}$ 
There are many kinds of balance assessment. Dynamic balance or functional mobility tests are balance assessment methods that is most related to the risk of fall. The examples of those are Berg Balance Scale (BBS) and Timed Up and Go (TUG) test. Both tests are often used in elderly and have a good correlation with objective balance test. ${ }^{4}$

Aging causes decrease of sensory, motor and cognitive function that can cause balance problem. Cognitive disorders have long been associated with incidence of fall, especially during dual-task activity. ${ }^{5}$ Degradation of cognitive function is more frequent in elderly living in nursing homes compared to those who lives in community. ${ }^{6}$ This study aimed to determine correlation between balance performance and cognitive status among elderly in nursing home.

\section{METHODS}

This study was conducted in Panti Sosial Tresna Wreda (nursing home) Budi Mulia 1, East Jakarta. Balance performance was evaluated using Timed Up and Go (TUG) test and Berg Balance Scale (BBS), while cognitive status was examined using Mini Mental State Examination (MMSE).

Timed Up and Go (TUG) measures how long time needed by a participant to stand from a standard chair, walk for 3-meters, turns $180^{\circ}$, walk back and sit down on the same chair. The longer time it takes, the balance become worse. Otherwise, for Berg Balance Scale (BBS), higher score of it means better balance. The BBS consists of 14 tasks to examine static and dynamic balance, scored 0 to 4 for each task. ${ }^{7,8}$

The inclusion criteria for subjects were: sixty years old or older, able to do ambulation with/without walking aid, manual muscle test (MMT) at least 4 in all extremity, able to understand instruction, willing to participate in this study. The exclusion criteria were uncorrected visual acuity $<3 / 60$ with finger count examination, uncorrected hearing problem that cause communication problem, severe neuromuscular or musculoskeletal condition.

Data were managed using SPSS 20 program. Since data were not normally distributed, Spearman test was done to analyze correlation between MMSE and balance performance (TUG and BBS).

\section{RESULTS}

There were 35 participants included in this study. Their characteristics are listed in table 1. The median age was 69 (60-94) years old. Median MMSE result was 21 (6-30). Most of the subjects $(31.5 \%)$ had not complete elementary school, even some of them (14.3\%) are illiterate. Only quarter of subjects earned secondary or higher education. 
Table 1. Subject characteristics

\begin{tabular}{lccc}
\hline \multicolumn{1}{c}{ Variable } & N & $\%$ & Median (Min-Max) \\
\hline Age (years) & & & $69(60-94)$ \\
\hline Sex & 10 & 28.6 & \\
\hline Male & 25 & 71.4 & \\
\hline Female & & & \\
\hline Educational level & 5 & 14.3 & \\
\hline Illiterate & 11 & 31.5 & $21(6-30)$ \\
\hline Elementary incomplete & 10 & 28.5 & $14.13(9.66-88.50)$ \\
\hline Elementary complete & 9 & 25.7 & $50(18-56)$ \\
\hline Secondary or higher & & & \\
\hline MMSE & & & \\
\hline TUG (seconds) & & & \\
\hline BBS & &
\end{tabular}

The median result of TUG was 14.13 (9.6688.50) seconds. The median BBS result was 50 (18-56). As shown in table 2, MMSE have negative strong correlation with TUG $(\mathrm{r}=-0.693 ; \mathrm{p}=0.000)$ and positive strong correlation with BBS $(r=0.640 ; p=0.000)$.

Table 2. Correlation of MMSE with balance performance

\begin{tabular}{lcc}
\hline & $\mathbf{r}$ & $\mathbf{p}$ \\
\hline MMSE - TUG & -0.693 & 0.000 \\
MMSE - BBS & 0.640 & 0.000 \\
\hline
\end{tabular}

\section{DISCUSSION}

This study held in a public nursing home in Jakarta, where most of the inhabitants were homeless. This economic background might be the reason why most of the subjects had low education level. The illiteracy rate in this study is $14.3 \%$, that is higher compared with illiteracy rate in Jakarta $(0.73 \%)$, even in total Indonesia population $(10.6 \%) .{ }^{9}$

As mention earlier, median subject's age was 69 years old and median MMSE was 21. Few studies had been done to get median value of MMSE based on age and education. A study in healthy individuals in Medan found the same number for median results of MMSE in above 60 years old population. However, similar study in Jakarta got higher result (26). For population in low education level (0-6 years of education), the median results of MMSE in both studies were 24 and $26 .{ }^{10}$ A study by Crum et al also found slightly higher results of MMSE among 65-69 years old elderly with 0-4 years of education, that was $22 .{ }^{11}$ It means, subjects in this study had lower cognitive 
performance compared to population of same age and same education level.

Elderly living in nursing home tend to have more cognitive problem compared to them in community. Beside low economy and educational level issues, it might because older adults having cognitive problem are more frequently sent to nursing home by their family. Their placement on nursing home itself is also a risk factor for further cognitive decline. ${ }^{6}$

The result of TUG was 14.13 (9.66-88.50) seconds. Shumway-cook et al published that TUG results 13.5 seconds is a cut off to predicts fall in elderly. ${ }^{12} \mathrm{SD}=6$, range $=65-85 \mathrm{It}$ means subjects in this study had risk of fall. Berg Balance Scale (BBS) results, that was 50 (18-56), however it still better than its cut off for fall risk, that is $46 .{ }^{13}$

Both TUG and BBS had strong correlation with cognitive performance. The better cognitive status, measured by MMSE, the shorter time needed for TUG test $(\mathrm{r}=-.693)$ and higher BBS score $(r=.640)$.

Cognitive and balance relationship usually studied in dual-task activity, such as walking while performing another task. ${ }^{5}$ In this study, our balance measurements are single task, however their correlation are strong for cognitive function. However, Tangen et al also found association between singletask balance test (Balance Evaluation System Test) and cognition. ${ }^{14}$ Single-task balance examination using posturography also associated with brain atrophy and hippocampal volume. ${ }^{15,16}$

One of the components of TUG test is gait speed. Few studies had been performed to see relation of cognitive function and gait speed. A meta-analysis concludes that the evidence for an association between gait speed and cognition in elderly is strong. ${ }^{17}$

The most cognitive domain that has been associated with balance and gait is executive function. Executive functions are mental processes needed when a person need to concentrate and pay attention. Although attention is more needed in dual-task walking, single-task balance assessment also associated with executive function. ${ }^{5,14}$ Hyperintensity of the white matter has been associated with lower executive function in elderly. ${ }^{18}$

The strong correlation between cognitive and balance gives challenge to prevent fall among elderly. A fall prevention program in nursing homes must include cognitive aspect in their physical activity and balance exercise. The most important is prevention and early detection for cognitive decline.

\section{CONCLUSION}

Cognitive function has strong correlation with balance performance among elderly in nursing home. Therefore, cognitive aspect should be included in fall prevention program.

\section{REFERENCES}

1. Kementerian Kesehatan RI. Analisis Lansia di Indonesia. Pusat Data dan Informasi Kementrian Kesehatan RI, Jakarta: 2017. 
2. Becker C, Rapp K. Fall Prevention in Nursing Homes. Clin Geriatr Med [Internet]. 2010;26(4):693-704. Available from: $\quad$ http://dx.doi.org/10.1016/j. cger.2010.07.004

3. Shumway-cook A, Woollacott M. Motor control: translating research into clinical practice. 4th ed. Philadelphia: Wolters Kluwer; 2012.

4. Sabchuk R, Bento P, Rodacki A. Comparison Between Field Balance Tests and Force Platform Locomotor Apparatus in Exercise and Sports. Rev Bras Med Esporte. 2012;18:404-8.

5. Amboni M, Barone $\mathrm{P}$, Hausdorff J. Cognitive Contributions to Gait and Falls: Evidence and Implications. Mov Disord. 2013;28(11):1520-33.

6. Harmand MG, Meillon C, Rullier L. Cognitive Decline After Entering a Nursing Home: A 22-Year Follow-Up Study of Institutionalized and Noninstitutionalized Elderly People. J Am Med Dir Assoc. 2014;2-6. Available from: http://dx.doi. org/10.1016/j.jamda.2014.02.006

7. Mancini M, Horak FB. The relevance of clinical balance assessment tools to differentiate balance deficits. Eur J Phys Rehabil Med. 2010;46(2):239-48.

8. Barry E, Galvin R, Keogh C, Horgan F, Fahey T. Is the Timed Up and Go test a useful predictor of risk of falls in community dwelling older adults : a systematic review and meta- analysis. BMC Geriatr. 2014;14(14).

9. Persentase Penduduk Buta Huruf Menurut Kelompok Umur.Badan Pusat
Statistik:2011-2018. 2019. Available at: https://bps.go.id/linkTableDinamis/view/ $\mathrm{id} / 1056$

10. Cheah E, Rajaram S, Chua $\mathrm{HC}$, et alManaging the cognitive impairment of elderly patients using the Mini Mental State Examination (MMSE)BMJ Supportive \& Palliative Care. 2011;1:95.

11. Chang SM, Lee DW, Kim KW, Bae JN, Lee J, Cho MJ. Measuring cognition in elderly people: Mini-Mental State Examination-Korean version. Chang, Sung Man. Alzheimer's \& Dementia: The Journal of the Alzheimer's Association. $2012 ; 8(4): 371$

12. Al-Aama T. Falls in the elderly: spectrum and prevention [published correction appears in Can Fam Physician. 2014;60(3):225]. Can Fam Physician. 2011;57(7):771-776.

13. Smith MI, de Lusignan S, Mullett $\mathrm{D}$, Correa A, Tickner J, Jones S. Predicting Falls and When to Intervene in Older People:A Multilevel Logistical Regression Model and Cost Analysis. PLoS One. 2016;11(7):e0159365. doi:10.1371/ journal.pone.0159365

14. Tangen GG, Engedal $\mathrm{K}$, Bergland A, Moger TA, Mengshoel AM. Relationships Between Balance and Cognition in Patients With Subjective Cognitive Impairment, Mild Cognitive Impairment , and Alzheimer Disease. Am Phys Ther Assoc. 2014;94(8):1123-34.

15. Kido T, Tabara Y, Igase M, Ochi N, Uetani E, Nagai $T$, et al. Postural Instability Is Associated with Brain Atrophy and 
Cognitive Impairment in the Elderly: The J-SHIPP Study. Dement Geriatr Cogn Disord. 2010;29:379-87.

16. Beauchet $\mathrm{O}$, Barden $\mathrm{J}$, Liu-ambrose $\mathrm{T}$, Chester VL, Szturm T, Allali G. The relationship between hippocampal volume and static postural sway : results from the GAIT study. Am Aging Assoc. 2016;38(19).

17. Peel NM, Alapatt L, Jones L, Hubbard R. The Association between Gait Speed and
Cognitive Status in Community-dwelling Older People: A Systematic Review and Metaanalysis. Journals Gerontol Ser A. 2018;74(6):943-8.

18. Murray ME, Senjem ML, Petersen RC, John H, Preboske GM, Weigand SD, et al. Functional Impact of White Matter Hyperintensities in Cognitively Normal Elderly. Arch Neurol. 2010;67(11):137985. 